DOI: $10.22630 / E I O G Z .2014 .105 .9$

Zeszyty Naukowe Szkoły Głównej Gospodarstwa Wiejskiego

Ekonomika i Organizacja Gospodarki Żywnościowej nr 105, 2014: 95-104

Piotr Grzegorz Pietrzak

Katedra Ekonomiki i Organizacji Przedsiębiorstw

Szkoła Główna Gospodarstwa Wiejskiego w Warszawie

\title{
Zagadnienia strategiczne Szkoły Głównej Gospodarstwa Wiejskiego w Warszawie na tle innych szkół wyższych
}

\section{Wstęp}

Warunki dyktowane przez rynek pracy, intensyfikacja niżu demograficznego, a także nasilająca się konkurencja na rynku edukacyjnym kreślą przed polskimi placówkami oświatowymi nowe wyzwania. Uczelnie w Polsce wymagają nie tylko wyższego dofinansowania, ale również nowoczesnego zarządzania. Ustawa Prawo o szkolnictwie wyższym zobligowała szkoły wyższe do sformułowania, a następnie wdrożenia strategii rozwoju. Poprawnie przygotowany dokument strategiczny zawiera sformułowaną misję działania oraz wizję przyszłości w określonym horyzoncie czasowym. Ponadto określa on główne cele funkcjonowania uczelni oraz definiuje działania niezbędne do ich realizacji.

Swoje strategie rozwoju opracowały m.in.: Uniwersytet Ekonomiczny w Poznaniu, Uniwersytet im. Adama Mickiewicza, Uniwersytet Warmińsko-Mazurski w Olsztynie czy Szkoła Główna Gospodarstwa Wiejskiego w Warszawie.

Celem niniejszego artykułu jest porównanie zagadnień strategicznych opracowanych przez powyższe szkoły wyższe z uwzględnieniem takich elementów, jak: misja, wizja i cele strategiczne.

\section{Istota misji i wizji}

Szkoły wyższe chcąc w prawidłowy sposób reagować na zmiany pojawiające się w otoczeniu, muszą posiadać jasno zdefiniowaną misję. Jest to pojęcie, które zalicza się do kategorii trudnych w jednoznacznym zdefiniowaniu. 
„Misja przede wszystkim wyraża zasadniczy cel istnienia organizacji. Po drugie (...) nakreśla z grubsza granice działalności, a więc odpowiada na pytania: w jaki sposób realizujemy cel organizacji, co jest naszym biznesem, a co nie jest naszym biznesem?” [Pietrzak 2007, s. 86]. W końcu misja określa podstawowe wartości, które są kluczowe dla tożsamości organizacji.

Podstawową rolę jaką odgrywa misja jest określenie warunków brzegowych dla strategii organizacji. Stąd przyjmowany „horyzont czasowy (...) jest odległy, często nieokreślony konkretnymi ramami czasowymi” [Pietrzak 2005, s. 38]. Poprawne sformułowanie misji powinno stanowić pierwszy krok w zarządzaniu strategicznym.

Kolejnym ważnym zagadnieniem przy tworzeniu strategii rozwoju jest wizja przyszłości. Oznacza ona pewien obraz przyszłości organizacji oraz jej docelowej pozycji na rynku [Drazżek i Niemczynowicz 2003, s. 33]. Należy podkreślić, iż wizja jest nie tylko wynikiem doświadczenia, wiedzy czy nawet umiejętności predykcji, ale przede wszystkim ambicji oraz chęci wykazania się kreatywnością.

Wśród najważniejszych funkcji wizji wyróżnia się [Hahn 1993, s. 21]:

- funkcję aktywizująca,

- funkcję kierunkującą i porządkująca,

- funkcję integracyjna,

- funkcję wspierającą.

Funkcja aktywizująca inspiruje, pobudza do działania. W tym kontekście wizja wyraża „konieczność radykalnej poprawy niepożądanej sytuacji lub potrzebę osiągnięcia przełomowych rezultatów przez organizację" [Pietrzak 2006, s. 19]. Dlatego jej podstawową rolą jest tworzenie napiętych, ambitnych celów. Wizja, wprowadzając organizację w ruch, odpowiada za dynamiczny aspekt strategii.

Funkcja porządkująca wytycza kierunek, do którego zmierza organizacja, ustalając jednocześnie jej cele. „Znaczenie wykonywanej pracy nadaje funkcja integracyjna, która wzbudza zaangażowanie pracowników oraz ich motywację" [Kowal 2009, s. 12]. Dopełnieniem powyższych funkcji jest funkcja wspierająca, gwarantująca sukces organizacji.

W literaturze przedmiotu relacja między misją a wizją ulega pewnemu rozmyciu. „Często wizja uważana jest za element składowy misji (...) zdarza się też, że wizja i misja rozumiane są jako odrębne kategorie” [Rokita 2005, s. 28]. Rozróżnienie tych pojęć jest jednak pomocne. Misja określa warunki brzegowe strategii, posiada odległy, często nieokreślony horyzont czasowy, a także tworzy ramy dla analizy strategicznej. Z kolei wizja jest odpowiedzialna za kreowanie napiętych i ambitnych celów dla strategii, jej horyzont czasowy 
przeważnie obejmuje okres 5 lat, a definicja powstaje na podstawie analizy strategicznej.

Obecnie szczególnie mocno akcentuje się potrzebę samoidentyfikacji szkół wyższych. Władze uczelni są zobligowane do myślenia strategicznego. Dobrze opracowana misja, a także wizja stają się podstawowym ruchem strategicznym, mogącym wpłynąć na przyszły sukces.

\section{Misje szkół wyższych}

„Współczesny uniwersytet w swojej misji ma zapisane trzy podstawowe zadania: kształcenie, badania naukowe i służbę publiczną" [Jóźwiak i Morawski 2009, s. 48]. Formułując misję, szkoły wyższe powinny mieć również na uwadze fakt działania w określonym otoczeniu lokalnym, a także globalnym. Zarówno edukacyjna, jak i badawcza misja uniwersytetów posiada publiczny charakter, co powoduje, że szkoły wyższe mają do wypełnienia szczególne zobowiązanie wobec całego społeczeństwa. Są one odpowiedzialne m.in. za poziom oferowanej nauki i badań, za sposób „korzystania z autonomii akademickiej i ograniczonych publicznych zasobów” [Jóźwiak i Morawski 2009, s. 48].

Zarówno Szkoła Główna Gospodarstwa Wiejskiego w Warszawie, jak i Uniwersytet Ekonomiczny w Poznaniu, Uniwersytet im. Adama Mickiewicza w Poznaniu czy Uniwersytet Warmińsko-Mazurski w Olsztynie określiły swoje misje działania. Ich treść zawiera tabela 1.

Przedstawione w tabeli 1 misje różnią się w swoim podstawowym kształcie, tym samym oddając specyfikę każdej ze szkół wyższych. Misja Szkoły Głównej Gospodarstwa Wiejskiego w Warszawie akcentuje rolę człowieka stanowiącego jej największe bogactwo oraz podkreśla troskę o dobre relacje międzyludzkie i ożywienie intelektualne polskiego społeczeństwa. Jednocześnie uczelnia nie zapomina o swoich korzeniach, zaznaczając, iż główne obszary badawcze koncentrują się wokół obszarów wiejskich oraz gospodarki żywnościowej.

Z kolei misja Uniwersytetu Ekonomicznego w Poznaniu eksponuje PRESTIŻ, będący akronimem słów: prawda, rzetelność, elitarność, szacunek, transparentność, innowacyjność i życzliwość. Tym samym uczelnia akcentuje wartości, które są kluczowe dla jej tożsamości.

Misja Uniwersytetu im. Adama Mickiewicza w Poznaniu w swojej treści uwypukla rozwój kapitału intelektualnego, który drzemie w pracownikach naukowych, technicznych, administracyjnych, a także w doktorantach i studentach. Ponadto uniwersytet chlubi się mianem uczelni europejskiej, która w swojej aktywności postępuje zgodnie z Wielką Kartą Uniwersytetów Europejskich. 
Tabela 1

Treść misji wybranych szkół wyższych

\begin{tabular}{|c|c|}
\hline Uczelnia & Treść misji \\
\hline SGGW & $\begin{array}{l}\text { Misją SGGW jest służenie rozwojowi gospodarczemu i intelektualnemu pol- } \\
\text { skiego społeczeństwa, ze szczególnym uwzględnieniem obszarów wiejskich, } \\
\text { gospodarki żywnościowej i szeroko rozumianego środowiska naturalnego. Sta- } \\
\text { wiamy sobie za cel prowadzenie na najwyższym poziomie badań naukowych } \\
\text { i kształcenia oraz działalności wdrożeniowej. } \\
\text { Podstawą tożsamości i sukcesów naszej Uczelni są wartości, takie jak: profesjo- } \\
\text { nalizm, dbałość o jakość, pracowitość oraz innowacyjność. }\end{array}$ \\
\hline UEP & $\begin{array}{l}\text { Jesteśmy wspólnotą akademicka, której zależy na budowaniu PRESTIŻ-u Uni- } \\
\text { wersytetu Ekonomicznego w Poznaniu. Prowadzimy badania naukowe, któ- } \\
\text { re istotnie wzbogacaja wiedzę z zakresu nauk ekonomicznych i pokrewnych, } \\
\text { a przez kształcenie studentów i doktorantów przygotowujemy na wysokim po- } \\
\text { ziomie kadry zdolne skutecznie sprostać wyzwaniom rynku pracy i podejmować } \\
\text { aktywność naukową. } \\
\text { Identyfikując się z Uniwersytetem Ekonomicznym w Poznaniu, który jest jedna } \\
\text { z czołowych uczelni ekonomicznych w Polsce o coraz większym znaczeniu na } \\
\text { arenie międzynarodowej, zabieramy głos opiniotwórczy i doradczy w istotnych } \\
\text { sprawach gospodarczych. }\end{array}$ \\
\hline UAM & $\begin{array}{l}\text { Uniwersytet imienia Adama Mickiewicza w Poznaniu, będąc czéścią Wielkopol- } \\
\text { ski, Polski i Europy, czerpiąc z tradycji, patrzy w przyszłość, silnym poziomem } \\
\text { oraz jednościa badań i kształcenia poszerza wiedze o otaczającym świecie, } \\
\text { tworzy elity życia gospodarczego i społecznego oraz kształtuje dziedzictwo kul- } \\
\text { turowe. }\end{array}$ \\
\hline UWM & $\begin{array}{l}\text { Pomnażanie kapitału intelektualnego służącego zrównoważonemu rozwojowi } \\
\text { regionu i kraju poprzez tworzenie przyjaznych warunków do kreowania i zdo- } \\
\text { bywania wiedzy. }\end{array}$ \\
\hline
\end{tabular}

Źródło: Opracowanie własne na podstawie Strategii SGGW do 2020 roku [2013, s. 5], Strategii UEP na lata 2013-2020 [2013, s. 11], Strategii UAM na lata 2009-2019 [2009 s. 6], Strategii UWM na lata 2010-2020 [2010, s. 6].

Misja Uniwersytetu Warmińsko-Mazurskiego jest najbardziej lapidarna w swojej treści. Opiera się ona na trzech filarach:

- $\quad$ uczelnia kreuje swoją przyszłość z wykorzystaniem potencjału ukształtowanego w przeszłości,

- główną siłą uczelni jest jej różnorodność,

- uczelnia łączy regionalizm z internacjonalizmem.

Pomimo pozornej rozbieżności w treści, podstawowym celem istnienia wymienionych uczelni jest rozwój kapitału intelektualnego, tkwiącego w pracownikach oraz w studentach, a także intensyfikacja prac badawczych oraz wysoka jakość kształcenia. Ponadto każda z misji akcentuje konieczność podejmowania działań na rzecz społeczności lokalnych, wypełniając tym samym swoją służbę 
publiczną. Należy jednak podkreślić, iż tylko misja SGGW prezentuje jej obszar branżowy, tj. tereny wiejskie, gospodarkę żywnościową i szeroko pojęte środowisko naturalne.

\section{Wizje szkół wyższych}

Następnym zagadnieniem, które pojawia się w strategii rozwoju, jest wizja przyszłości, pełniąca niejako funkcję busoli. Opisuje ona pożądany stan przyszłości uczelni w przyjętym horyzoncie czasowym. Wizja jest motorem zmian oraz odpowiada za dynamiczny aspekt strategii.

Wizja Szkoły Głównej Gospodarstwa Wiejskiego w Warszawie opiera się na podziale zastosowanym w Zrównoważonej Karcie Wyników. Dla każdej z perspektyw (interesariuszy, procesów, potencjału, finansowej) został stworzony pożądany obraz przyszłości (tab. 2), co wpływa na czytelność i jasność przekazu.

W przypadku wizji Uniwersytetu Ekonomicznego w Poznaniu widoczne jest silne dążenie do zwiększenia rozpoznawalności uczelni na arenie międzynarodowej. Brak podziału na cztery perspektywy czyni ją mniej czytelną niż ta stworzona przez SGGW.

\section{Tabela 2}

Wizja SGGW

\begin{tabular}{|c|c|}
\hline Perspektywa & Przyjęte założenia \\
\hline Interesariuszy & $\begin{array}{l}\text { - Wysoki poziom jakości studentów } \\
\text { - Większa liczba i wyższa ranga projektów badawczych } \\
\text { - Silniejsza więź z praktyką gospodarczą jako odbiorcą usług badawczo- } \\
\text {-doradczych }\end{array}$ \\
\hline Procesów & $\begin{array}{l}\text { - Kształcenie kompetencji przydatnych na rynku pracy, większa mobilnośćć } \\
\text { studentów i doktorantów, uczelnia jeszcze bardziej przyjazna studentom } \\
\text { - Zwiększona aktywność w środowisku naukowym w kraju i zagranica, } \\
\text { większa międzynarodowa widoczność badań } \\
\text { - Transfer wiedzy do gospodarki znaczącym filarem działalności Uczelni }\end{array}$ \\
\hline Potencjału & $\begin{array}{l}\text { - Rozwój zaplecza bibliotecznego i informatycznego dla dydaktyki } \\
\text { - Kadra naukowa - zmotywowana, mobilna, dbająca o szybki rozwój na- } \\
\text { ukowy } \\
\text { - Zarządzanie uczelnią - sprawna i przyjazna administracja, doskonalenie } \\
\text { systemu zarządzania jakościa kształcenia, skuteczne wdrażanie strategii }\end{array}$ \\
\hline Finansowa & $\begin{array}{l}\text { - Stabilne finansowanie działalności na odpowiednim poziomie dzięki } \\
\text { wzrostowi przychodów oraz poprawie efektywności kosztowej }\end{array}$ \\
\hline
\end{tabular}

Źródło: Strategia SGGW do 2020 roku [2013, s. 6]. 
Wizja UEP w 2020 roku zawiera zbiór następujących celów:

- $\quad$ uniwersytet poświadczy swoją pozycję naukową i dydaktyczną na międzynarodowym forum,

- $\quad$ wzrośnie rozpoznawalność i nowoczesność uczelni,

- $\quad$ będą panowały dogodne warunki do prowadzenia badań, jak i do kształcenia studentów,

- $\quad$ wzmocni się rola opiniotwórcza i doradcza uniwersytetu,

- $\quad$ placówka będzie instytucją sprawnie zarządzana, wyznaczającą cele, które zapewnią jak najlepsze uwzględnienie potrzeb lokalnej, krajowej i międzynarodowej gospodarki.

Z kolei na obraz Uniwersytetu im. Adama Mickiewicza w Poznaniu w 2019 roku składają się ambitne cele, które można podzielić na dwie kategorie. Pierwsza dotyczy tego, jaki będzie uniwersytet, druga wskazuje te elementy, które będą decydowały o jego rozpoznawalności (tab. 3).

Tabela 3

Wizja UAM

\begin{tabular}{|c|c|}
\hline Cele odnoszące się do funkcjonowania uniwersytetu & $\begin{array}{l}\text { Cele odnoszące się do } \\
\text { postrzegania uniwersytetu }\end{array}$ \\
\hline $\begin{array}{l}\text { - podejmuje światowe wyzwania, wielkie projekty i wspól- } \\
\text { ne inicjatywy z najwybitniejszymi ośrodkami akademic- } \\
\text { kimi na świecie } \\
\text { - jest jednym z czołowych uniwersytetów w Europie, } \\
\text { obecnym w światowych rankingach, o wysokim pozio- } \\
\text { mie i innowacyjności badań, przyjaznym studentom, } \\
\text { znakomicie zarządzanym, słynącym z tolerancji i róż- } \\
\text { norodności } \\
\text { - jest autorytetem w życiu społecznym i politycznym kraju } \\
\text { oraz oparciem dla gospodarki } \\
\text { - stanowi integralna czéść miasta, dzięki czemu akade- } \\
\text { micki Poznań zdecydowanie wyróżnia się na tle Polski } \\
\text { - gwarantuje w ramach nowoczesnych kampusów uni- } \\
\text { wersyteckich warunki studiowania i pracy naukowo-ba- } \\
\text { dawczej odpowiadające najwyższym światowym stan- } \\
\text { dardom }\end{array}$ & $\begin{array}{l}\text { - łaczenie śmiałych wizji rozwo- } \\
\text { ju z poszanowaniem tradycyj- } \\
\text { nych wartości akademickich } \\
\text { - szczególna otwartość na } \\
\text { wszelkie innowacje nauko- } \\
\text { wo-badawcze, dydaktyczne } \\
\text { i organizacyjne oraz wyjątko- } \\
\text { wa odwaga w ich wspieraniu } \\
\text { - dyplom bardzo wysoko cenio- } \\
\text { ny przez pracodawców }\end{array}$ \\
\hline
\end{tabular}

Źródło: Opracowanie własne na podstawie Strategii UAM na lata 2009-2019 [2009 s. 9].

Uniwersytet Warmińsko-Mazurski w Olsztynie w 2020 roku widzi w sobie silny ośrodek naukowo-badawczy, odgrywający kluczową rolę w życiu gospodarczym województwa. Ponadto uczelnia pragnie zbudować silną tożsamość regionalną wynikającą z uwarunkowań historycznych oraz geograficznej lokalizacji. 
Wizje opracowane przez Szkołę Główną Gospodarstwa Wiejskiego w Warszawie, Uniwersytet Ekonomiczny w Poznaniu, Uniwersytet im. Adama Mickiewicza w Poznaniu oraz Uniwersytet Warmińsko-Mazurski w Olsztynie różnią się zarówno pod względem stopnia szczegółowości, jak również w niewielkim stopniu pod względem przyjętego horyzontu czasowego.

\section{Cele strategiczne}

Kolejnym elementem wyodrębnionym w strategiach rozwoju są cele strategiczne. Kluczowe znaczenie posiadają decyzje związane z określeniem optymalnej liczby celów oraz decyzje związane z wyborem narzędzia umożliwiającego skuteczną ich realizację, a następnie pomiar i kontrolę. Zarówno Szkoła Główna Gospodarstwa Wiejskiego w Warszawie, jak i Uniwersytet Ekonomiczny w Poznaniu, Uniwersytet im. Adama Mickiewicza w Poznaniu czy Uniwersytet Warmińsko-Mazurski w Olsztynie sformułowały w swoich strategiach rozwoju ambitne oraz mierzalne cele strategiczne. Ich treść w wielu przypadkach jest zbieżna. Uczelnie dążą przede wszystkim do wzrostu poziomu i jakości procesu dydaktycznego, zwiększenia zauważalności wyników badań na arenie międzynarodowej, a także nawiązania współpracy ze sferą szeroko pojętego biznesu.

Tworząc narzędzia implementacji strategii, uczelnie nawiązały do metodyki Zrównoważonej Karty Wyników. Należy podkreślić, że wyłącznie strategia Szkoły Głównej Gospodarstwa Wiejskiego w Warszawie nawiązuje do klasycznej wersji BSC (podział na cztery perspektywy: interesariuszy, procesów, potencjału i finansów). Dzięki sformułowanym miernikom strategia SGGW pozwala ocenić stopień realizacji postawionych celów. Ponadto, za pomocą mapy strategii, ukazuje powiązania przyczynowo-skutkowe między celami w ramach perspektyw oraz pomiędzy nimi.

Dla mierników wchodzących w skład strategii został stworzony „słownik” określający m.in. ich formułę, miano, polaryzację czy uzasadnienie zastosowania. Zmodyfikowane BSC Szkoły Głównej Gospodarstwa Wiejskiego w Warszawie to narzędzie, które pozwala na ciągłe monitorowanie postępów w realizacji celów określonych w strategii rozwoju na lata 2011-2020.

Zarówno Uniwersytet Ekonomiczny, jak i Uniwersytet im. Adama Mickiewicza w Poznaniu narzędziem implementacji strategii uczynił Karty Strategiczne, które swoją budową odbiegają od klasycznego modelu BSC. Karty te przede wszystkim pomijają podział na cztery kluczowe perspektywy oraz ignorują wizualizację połączeń przyczynowo-skutkowych między celami w postaci mapy strategii. 
W przypadku Uniwersytetu Warmińsko-Mazurskiego w Olsztynie trudno jednoznacznie wskazać narzędzie służące wdrożeniu strategii. Uczelnia posiada opracowaną macierz ukazującą tematy strategiczne w trzech podstawowych perspektywach. Narzędzie to pozwala wyodrębnić główne cele strategiczne uniwersytetu, jednakże nie przesądza o ich realizacji. Ponadto w dokumencie została pominięta odpowiedzialność za wykonanie poszczególnych celów.

\section{Podsumowanie}

Opracowanie strategii rozwoju jest obecnie dość powszechnym zjawiskiem wśród polskich szkół wyższych. Stworzenia i implementacji własnej strategii podjeły się m.in. Szkoła Główna Gospodarstwa Wiejskiego w Warszawie, Uniwersytet Ekonomiczny w Poznaniu, Uniwersytet im. Adama Mickiewicza w Poznaniu czy Uniwersytet Warmińsko-Mazurski w Olsztynie. Analiza porównawcza podstawowych zagadnień strategicznych opracowanych przez szkoły wyższe uwzględnia takie elementy, jak: misję, wizję, cele strategiczne (tab. 4).

Jak wynika z tabeli 4, każda ze zbadanych uczelni posiada opracowaną misję. Jednakże jedynie Szkoła Główna Gospodarstwa Wiejskiego w Warszawie oraz Uniwersytet Ekonomiczny w Poznaniu w jej treści zaprezentowały podstawowe

\section{Tabela 4}

Analiza porównawcza podstawowych zagadnień strategicznych uczelni

\begin{tabular}{|c|l|c|c|c|c|}
\hline $\begin{array}{c}\text { Wyszczegól- } \\
\text { nienie }\end{array}$ & Kryterium & SGGW & UEP & UAM & UWM \\
\hline \multirow{4}{*}{ Misja } & Wyraża zasadniczy cel istnienia uczelni & 1 & 1 & 1 & 1 \\
\cline { 2 - 6 } & Nakreśla granice działalności uczelni & 1 & 1 & 1 & 0 \\
\cline { 2 - 6 } & $\begin{array}{l}\text { Definiuje podstawowe wartości, kluczo- } \\
\text { we dla tożsamości uczelni }\end{array}$ & 1 & 1 & 0 & 0 \\
\hline \multirow{3}{*}{ Wizja } & Kreuje wyzwania (napięte cele) & 1 & 1 & 1 & 1 \\
\cline { 2 - 6 } & $\begin{array}{l}\text { Posiada relatywnie długi horyzont cza- } \\
\text { Cowy }\end{array}$ & 1 & 1 & 1 & 1 \\
\hline \multirow{3}{*}{$\begin{array}{c}\text { Cele } \\
\text { strategiczne }\end{array}$} & Opracowana mapa strategii & 1 & 0 & 0 & 0 \\
\cline { 2 - 6 } & Wyodrębnione tematy strategiczne & 1 & 0 & 0 & 0 \\
\cline { 2 - 6 } & Opracowane słowniki mierników & 1 & 1 & 1 & 0 \\
\hline
\end{tabular}

Źródło: Opracowanie własne. 
wartości uważane za kluczowe dla ich tożsamości. Ponadto wyłącznie SGGW nakreśliła swój obszar branżowy, tj. obszary wiejskie, gospodarkę żywnościową oraz środowisko naturalne.

Również w każdej z zaprezentowanych strategii rozwoju znalazła się wizja przyszłości. Zarówno SGGW, jak i UEP, UAM oraz UWM opracowały napięte cele strategiczne, których realizacja miałaby się przyczynić do urzeczywistnienia obrazu przyszłości.

Każda z uczelni opracowała także cele strategiczne. Jednakże jedynie SGGW posiada mapę strategii ukazującą powiązania przyczynowo-skutkowe między celami wewnątrz perspektyw i pomiędzy nimi oraz posiada wyodrębnione tematy strategiczne.

W kolejnym kroku uczelnie powinny dołożyć wszelkich wysiłków do integracji opracowanych strategii z bieżącą działalnością. Kluczowego znaczenia nabiera opracowanie inicjatyw strategicznych oraz harmonizacja celów na jednostki wewnętrzne oraz pomocnicze.

\section{Literatura}

DRAZŻEK Z., NIEMCZYNOWICZ B.: Zarzqdzanie strategiczne przedsiębiorstwem, Polskie Wydawnictwo Ekonomiczne, Warszawa 2003.

HAHN D.: Tendencje rozwoje zarzqdzania strategicznego, Organizacja i Kierowanie, nr 2/93, s. 21.

JÓŹWIAK I., MORAWSKI R.Z.: Społeczna rola szkolnictwa wyższego i jego misja publiczna w perspektywie dekady 2010-2020, Polskie Szkolnictwo wyższe. Stan, uwarunkowania i perspektywy, Wyd. Uniwersytetu Warszawskiego, Warszawa 2009.

KOWAL B.: Zrównoważona Karta Wyników jako narzędzie realizacji strategii w przedsiębiorstwie górniczym węgla kamiennego, Publikowana rozprawa doktorska, Kraków 2009.

PIETRZAK M.: Audyt strategiczny w projekcie wdrożenia Balanced Scorecard. Controlling i Rachunkowość Zarządcza, nr 7/2005, s. 38.

PIETRZAK M.: Opracowanie koncepcji biznesowej Balanced Scorecard - mierniki i wartości docelowe, Controlling i Rachunkowość Zarządcza, nr 3/2006, s. 19.

PIETRZAK M.: Balanced Scorecard - Zrównoważona Karta Wyników, w: Metody i technik menedżerskie, pod. red. M. Pietrzaka, Wydawnictwo SGGW, Warszawa 2007.

ROKITA J.: Zarzqdzanie strategiczne. Tworzenie i utrzymanie przewagi konkurencyjnej, Polskie Wydawnictwo Ekonomiczne, Warszawa 2005.

Strategia Rozwoju Uniwersytetu im. Adama Mickiewicza w Poznaniu na lata 2009-2019.

Strategia Rozwoju Uniwersytetu Warmińsko-Mazurskiego w Olsztynie na lata 2010-2020.

Strategia Szkoły Głównej Gospodarstwa Wiejskiego w Warszawie do roku 2020.

Strategia Uniwersytetu Ekonomicznego w Poznaniu na lata 2013-2020. 


\title{
Strategic issues in Warsaw University of Life Sciences compared to other universities in Poland
}

\begin{abstract}
Obligating put on Polish universities by the Ministry to develop strategies as well as expecting process of deepening demographic bust, compels the search for new management tools. One of the proposed solutions is Balanced Scorecard. The author of this article has compared strategies of four Polish universities: Warsaw University of Life Sciences, Poznań University of Economics, Adam Mickiewicz University in Poznań and Warmian and Mazurian University in Olsztyn. He has taken into account the most important strategic issues like: mission, vision and strategic objectives.
\end{abstract}

